At the outbreak of the Second World War he volunteered for service; but his age prohibited him from seeing active service, though he did good work in charge of a base camp in Abyssinia. Previous to that he compiled a very useful little gazetteer of Abyssinia for the use of the troops. After the defeat of the Italians, Shortridge returned to the Museum, and as soon as the War was over started making expeditions again. In 1946, accompanied by $\mathrm{Mr}$. A. S. Vernay, of New York, who financed the expedition, Shortridge extended his investigations to Nyasaland. Only last year, when sixty-eight, he made a very successful collecting trip to the Albany district.

During his twenty-eight years service in the Kaffrarian Museum, Shortridge undertook thirteen collecting expeditions in search of mammals, with the result that the Museum now contains some 25,000 specimens-a unique collection of South African mammalian fauna. Although Shortridge's chief interest was in mammals, he did not neglect other groups, and, as a result of his extensive collecting, the Museum collections have quite outgrown the original building. Recently plans were prepared for building an extension.

Shortridge was a great collector, and wherever he went he always made friends and interested people in his work. He was the leading authority on South African mammals, and though he did not write many papers, he had a very wide knowledge which was always available to his correspondents. Expeditions cannot be run without funds, and Shortridge had a wonderful way of raising money and co-operating with other museums.

\section{Prof. Douglas Hay}

In these days, when the appeal is for men of experience to run the world's industries, the sudden silencing of an authentic voice is a matter for sorrow deeper than the grief so often hidden beneath the vesture of public or official mourning. The death, on February 24 at the age of sixty, of Prof. Douglas Hay, one of the two chief mining engineers of the National Coal Board and a past-president of the Institution of Mining Engineers, has left a gap in the industry that will be hard to fill. For he had travelled the trying road of experience and passed the milestones of change in mining until he reached the highest position in his profession. Those who knew that quiet, unassuming charm which was so big a feature of his life understood fully that it was an advancement due not only to his great technical and administrative ability, but also to a sympathetic personality that enabled him to get on well with those with whom he came into contact. He won the affection of miners through sympathetic personality, an unending thought for others, and a friendship that had no bounds.

Douglas Hay went to King Edward VI Grammar School, East Redford, and later to University College, Nottingham, with mining in his blood. His father was Mr. W. Hay, a mining engineer, of Sheffield. There were no favours for young Hay. He worked underground at Tinsley Park Colliery, was later apprenticed at Shirebrook Colliery, Notts, and in 1910 he obtained his first-class colliery manager's certificate; two years later, he received the James Forrest Medal and Miller Prize of the Institution of Civil Engineers. He delivered the first Cadman
Memorial Lecture of the Royal Society of Arts in 1947, and the William Menelaus Lecture in the same year to the South Wales Institute of Engineers. $\mathrm{He}$ was honorary professor of mining in the University of Sheffield.

Prof. Hay had been H.M. Inspector of Mines in Durham and later in North Staffs. He was general manager of Newton Chambers and Co.'s collieries, Chapeltown; managing director of Barrow Barnsley Main Collieries, Ltd., and of the Barnsley District Coking Co., Ltd.; and technical director of Wombwell Main Colliery Co., Ltd. He was a member of the Holland Committee on Qualifications of Colliery Officials ; consulting engineer, in conjunction with the late Dr. J. S. Haldane, on ventilation problems of the Mersey Tunnel ; and later adviser on ventilation for the Dartford-Purfleet Tunnel under the Thames, and important war-time underground factories.

The Midland Institution of Mining Engineers elected him president in 1923, and he remained in that position until 1936. In 1928 he became a member of the Council of the Institute of Mining Engineers. Mining gave him its greatest honour when, in 1945, the Institute of Mining Engineers elected him as its president, and the work which he did in the three years of his office will always remain his memorial.

Prof. Hay's outstanding contribution, which will have far-reaching influence, perhaps for generations, was his work, often against strong opposition, in connexion with the raising of the standard and professional status of mining engineers, culminating in the associate membership examinations of the Institute of Mining Engineers announced in 1946, the introduction of groups, and the raising of the qualifications required for admission, pending the introduction in 1952 on a compulsory basis of the associate membership examinations.

\section{Mr. John Ardagh}

JoHN ARDAGH /W fontorn at Fulham on June 15, 1885, and died Maidstone on March 8 last. At an early oone was taken to Ireland by his parents, apd fen fourteen, became a boy attendant at the Dufy Museum. In 1919 he was transferred to the British(Museum (Natural History) and worked in the herbarium. After three years he was appointed clerk-in-charge of the Botanical Library. He soon proved his capabilities as a librarian and gradually built up a considerable reputation among his colleagues and with visitors. The richness of the Library in manuscripts and drawings, as well as in old books, provided him with abundant scope for the exercise of his special qualities. He was ever ready to give freely of his knowledge or to search for facts of interest to others. He contributed several bibliographical notes to the Journal of Botany, and, with H. W. Renkema, gave an account of the various editions of A. B. Lambert's "Pinus", in the Journal of the Linnean Society. He was elected an associate of the Linnean Society in 1939. In addition to his keenness on everything connected with the 'circles' of Sloane and Banks, he made a hobby of the history of old London, and often contributed to Notes and Queries.

Ardagh was of quiet and somewhat stolid demeanour, slow moving but mentally alert, and warmhearted. He retired from the Museum in September 1947 on account of ill-health, and was never well enough to visit it again. J. RAMSBOTTOM 